\title{
PENGARUH AKTIVITAS MEDIA TWITTER BRI SYARIAH TERHADAP KEPUASAN NASABAH BRI SYARIAH
}

\section{THE INFLUENCE OF BRI SYARIAH TWITTER ACTIVITY AGAINST CUSTOMER'S SATISFACTION}

\author{
Yuda Permana1a Tuti Kurnia ${ }^{2}$ \\ ${ }^{1}$ Jurusan Ekonomi Islam Fakultas Ekonomi Islam Universitas Djuanda, Jl. Tol Ciawi No. 1, Kotak Pos \\ 35 Bogor 16770. \\ ${ }^{2}$ Jurusan Ekonomi Islam Fakultas Ekonomi Islam Universitas Djuanda, Jl. Tol Ciawi No. 1, Kotak Pos \\ 35 Bogor 16770
}

(Diterima oleh Dewan Redaksi: 14-03-2014)

(Dipublikasikan oleh Dewan Redaksi: 01-06-2015 )

\begin{abstract}
BRI Syariah is one of official accounts of BRI Syariah twitter which has followed by about 68,208 followers and is the highest number of tweets among other Islamic bank accounts as much as 32.538 tweets. The purpose of this research was to determine the activities undertaken by social media officers of @BRISyariah and how they affect their costumers' satisfaction.

This research was conducted online by distributing questionnaires to $30 \mathrm{BRI}$ Syariah customers who become followers of @BRISyariah account using accidental sampling technique. The research was done using descriptive quantitative data analysis technique with likert scale and logistic regression analysis.

Based on the data analyzing which has done, variable reliability can not be done due to logistic regression analysis of all respondents in just one category. The three remaining variables, which are responsiveness, assurance and empathy have contributed in increasing customer satisfaction of BRI Syariah. In these variables, empathy has greater odds ratio value than any other variables, that is 2,667. Empathy itself is an individual attention given by the @BRISyariah account to BRI Syariah customers who active on twitter social networking site.
\end{abstract}

Keyword : Social Media, Twitter, BRI Syariah

\begin{abstract}
ABSTRAK
BRI Syariah merupakan salah satu akun twitter resmi BRI Syariah yang telah menjaring sekitar 68.208 followers dan memiliki jumlah tweet terbanyak di antara akun bank syariah lainnya sebanyak 32.538 tweets. Tujuan dari penelitian ini adalah untuk mengetahui aktivitas yang dilakukan oleh pengelola media sosial twitter @BRISyariah serta bagaimana pengaruhnya terhadap kepuasan para nasabahnya.

Penelitian ini dilakukan dengan cara menyebarkan kuesioner online kepada 30 nasabah BRI Syariah yang menjadi followers akun @BRISyariah dengan menggunakan teknik accidental sampling. Penelitian dilakukan menggunakan teknik analisis data deskriptif kuantitatif dengan menggunakan skala likert dan analisis regresi logistik.
\end{abstract}


Berdasarkan analisis data yang dilakukan, variabel reliability tidak dapat dilakukan analisis regresi logistik dikarenakan semua jawaban responden hanya pada satu kategori saja. Tiga variabel sisanya, yaitu responsiveness, assurance dan empathy memiliki kontribusi dalam meningkatkan kepuasan nasabah BRI Syariah. Pada variabel tersebut, variabel empathy memiliki nilai odds ratio lebih besar dibandingkan dengan variabel lainnya, yaitu sebesar 2,667. Empathy sendiri merupakan perhatian secara individual yang diberikan oleh akun @BRISyariah terhadap nasabah BRI Syariah yang aktif di situs jejaring sosial twitter.

Kata kunci :Media sosial,Twitter, BRI Syariah

Permana. 2014. Pengaruh Aktivitas Media Twitter BRI Syariah Terhadap Kepuasan Nasabah BRI Syariah (1): 38 - 53.

\section{PENDAHULUAN}

Dalam strategi memperluas pangsa pasar dan seiring kemajuan teknologi juga, bank syariah mencoba mendongkrak pangsa pasar yang ada, salah satunya adalah melalui dunia maya seperti social media. Hal tersebut dilater belakangi karena sekarang ini banyak perusahaanperusahaan di Indonesia yang sudah memiliki akun-akun social media, dimana akun-akun tersebut bertujuan untuk meningkatkan layanan purna jual mereka serta menjaga hubungan dengan konsumennya agar tetap terjaga dengan baik. Para konsumen dan khalayak umum dapat berkomunikasi secara langsung kepada akun-akun social media tersebut, baik sekedar menanyakan produknya, mengeluh terhadap produknya, memberikan apresiasi dan lain sebagainya. Sehingga para konsumen dapat lebih merasa terpuaskan keinginannya dengan adanya layanan online seperti ini. Selain itu pemanfaatan lewat social media ini tergolong praktis, karena cukup dengan akses internet dan gadget seperti Personal Computer (PC), laptop, smartphone dan lainnya sudah dapat mengakses situs social media yang dinginkan. Lalu dengan adanya fasilitas tersebut juga memungkinkan satu user bertukar pikiran dan wawasan dengan user lainnya. Contoh dari social media saat ini di antaranya seperti wikipedia, twitter, youtube, facebook, game online, second life dan lain sebagainya.

Social media yang sedang tren di Indonesia saat ini salah satunya adalah Twitter. Twitter adalah layanan jejaring sosial dan microblog daring yang memungkinkan penggunanya untuk mengirim dan membaca pesan berbasis teks hingga 140 karakter, yang dikenal dengan sebutan kicauan (tweet) ( Wikipedia, 2013 ). Twitter juga disebutsebut sebagai "pesan singkat dari internet". Data yang diperoleh dari sebuah lembaga analisis yaitu Semiocast menunjukkan bahwa Indonesia merupakan negara ke lima dunia dengan jumlah user twitter lebih dari 15 juta akun. Berikut grafik yang menunjukkan data tersebut.

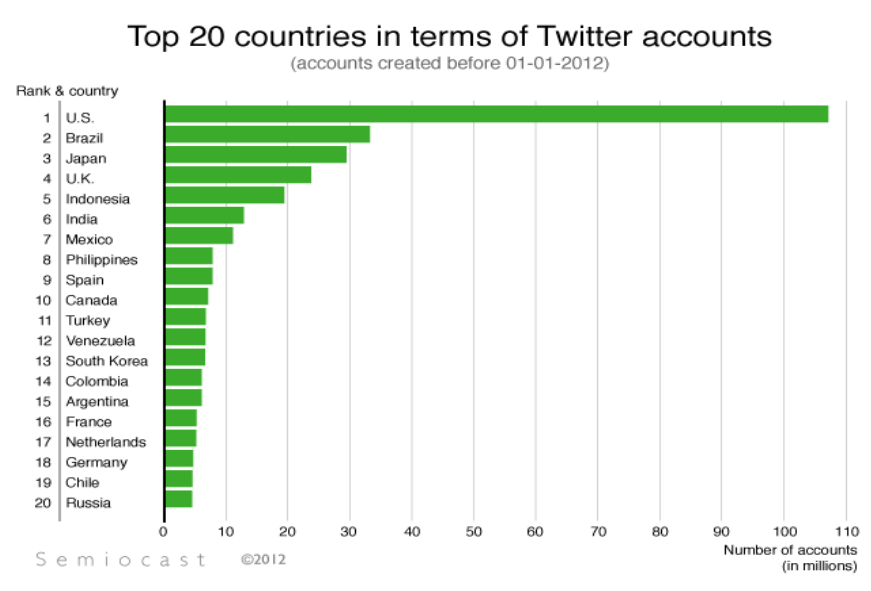

Gambar 1 Negara dengan Jumlah Pengguna Twitter Terbanyak di Dunia Sumber: situs www.dgtraff.com 
Berdasarkan jumlah tweet terbanyak di dunia, Jakarta menempati urutan pertama, diikuti oleh Bandung diurutan keenam. Berikut grafik yang menunjukkan data tersebut ( DGtraffic, 2013 ).

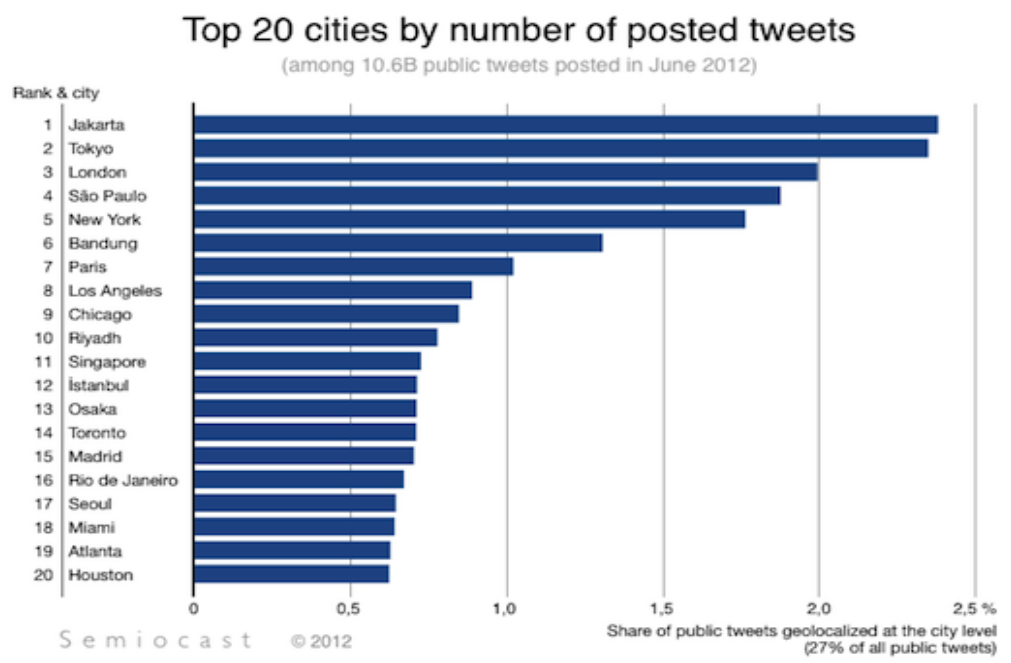

Gambar 2. Negara dengan Jumlah Pengguna Twitter Terbanyak di Dunia Sumber: situs www.dgtraffic.com

Dari penelitian yang dilakukan oleh lembaga Semiocast tersebut mengindikasikan bahwa banyak masyarakat di Indonesia yang aktif dalam akun jejaring sosial twitter ini. Dengan begitu ini merupakan kesempatan yang baik untuk perbankan syariah dalam meningkatkan pelayanannya, demi tercapai kepuasan para nasabahnya yang aktif dalam situs jejaring sosial twitter.

Berkaitan dengan hal di atas, beberapa dari perbankan syariah sudah memiliki akun twitternya. Salah satunya adalah PT. BRI Syariah dengan akun resminya sendiri adalah @BRISyariah telah menjaring sekitar 68.208 followers dan memiliki jumlah tweet terbanyak di antara akun bank syariah lainnya sebanyak 32.538 tweets. Aktivitas yang dilakukan akun twitter BRI Syariah sendiri di antaranya seperti melayani keluhan nasabahnya, memberikan informasi mengenai kode

transfer, mobile banking, dan lain sebagainya.

Akun@BRISyariah sendiri dibuat demi tercapai kepuasan nasabahnya, dimana dengan adanya akun twitter tersebut para nasabah menjadi lebih mudah dalam berinteraksi dengan pihak BRI Syariah. Namun demikian media twitter membatasi penggunanya untuk mengirimkan teks terbatas hingga 140 karakter saja. Selain itu tidak semua followers BRI Syariah dapat dilayani keluhannya satu per satu. Sehingga hal ini dapat berpengaruh pula pada tingkat kepuasan nasabahnya. Berdasarkan uraian di atas, maka pertanyaan penelitian ini adalah:

1. Bagaimana aktivitas yang dilakukan pengelola media twitter BRI Syariah?

2. Bagaimana pengaruh aktivitas media twitter BRI Syariah terhadap kepuasan nasabah BRI Syariah.

\section{MATERI DAN METODE}

Jenis penelitian ini merupakan jenis penelitian kuantitatif, dimana penelitian ini bermaksud untuk memberikan gambaran mengenai pengaruh aktivitas media twitter BRI Syariah terhadap kepuasan nasabah BRI Syariah. Penentuan jumlah sampel dalam penelitian ini menggunakan metode Joseph F. Hair, yaitu 15 atau 20 kali variabel bebas, sehingga akan didapatkan 
hasilnya yaitu $15 \times 2$ (jumlah kategori) = 30 ( Younie, 2011 ). Teknik sampling yang digunakan adalah teknik accidental sampling, dimana teknik ini merupakan teknik penentuan sampel berdasarkan kebetulan, yaitu siapa yang kebetulan bertemu dengan peneliti dapat dijadikan sampel jika dipandang cocok ( Younie, 2011 ). Teknik pengumpulan data dalam penelitian ini adalah melalui kuesioner online lewat fasilitas Google Docs, yang dilakukan dengan cara memberikan pertanyaan kepada nasabah BRI Syariah di situs jejaring sosial twitter untuk dijawab dengan pilihan jawaban yang telah disediakan. Teknik analisis data dalam penelitian ini menggunakan regresi logistik dengan beberapa tahapan sebagai berikut:

1. Skala Likert adalah skala yang dapat digunakan untuk mengukur sikap, pendapat dan persepsi seseorang tentang suatu objek atau fenomena tertentu. Dalam penelitian ini pernyataan yang ada diberikan skor dari 4, 3, 2 dan 1. Pengukurannya sendiri terdiri atas ( Syofian, 2013 ):
a. Sangat Setuju (SS)
$=4$
b. Setuju (S)
$=3$
c. Tidak Setuju (TS)
$=2$
d. Sangat Tidak Setuju (STS) $=1$

2. Regresi logistik dimana analisis ini digunakan untuk mengetahui pengaruh aktivitas media twitter BRI Syariah terhadap kepuasan nasabah BRI Syariah. Rumus regresi logistik dalam penelitian ini adalah sebagai berikut ( Damodar, 1997 ):
$Y_{i}=\alpha+\beta X_{i}+\mu_{i}$

Keterangan:

$\mathrm{Y}_{\mathrm{i}} \quad=$ Peluang Kepuasan Nasabah BRI Syariah

$\mathrm{X}_{\mathrm{i}} \quad=$ Aktivitas Media Twitter BRI Syariah

$\alpha, \beta=$ Konstanta atau parameter

$\mu_{\mathrm{i}} \quad=$ Standar Error

3. Uji validitas adalah suatu langkah pengujian yang dilakukan terhadap isi (content) dari suatu instrumen, dengan tujuan untuk mengukur ketepatan instrumen yang digunakan dalam suatu penelitian.

4. Uji reliabilitas adalah proses pengukuran terhadap ketepatan (konsisten) dari suatu instrumen. Pengujian ini dimaksudkan untuk menjamin instrumen yang digunakan merupakan sebuah instrumen yang handal, konsistensi, stabil dan dependabilitas, sehingga bila digunakan berkali-kali dapat menghasilkan data yang sama (Lestariningsih, 2011).

Dalam penelitian ini juga menggunakan variabel dummy, dimana sebelum ke tahap pembentukan variabel dummy, pada data kategori dirubah terlebih dahulu kedalam bentuk kode angka ( BESRAL, 2010 ), lalu membentuk variabel buatan yang mengambil nilai 1 atau 0 ( Damodar, 1997 ). Dalam penelitian ini terdapat 5 variabel kualitatif yang harus dirubah kedalam variabel dummy, seperti pada tabel berikut ini:

Tabel 1 Variabel Dummy Pengaruh Aktivitas Media Twitter BRI Syariah terhadap Kepuasan Nasabah BRI Syariah

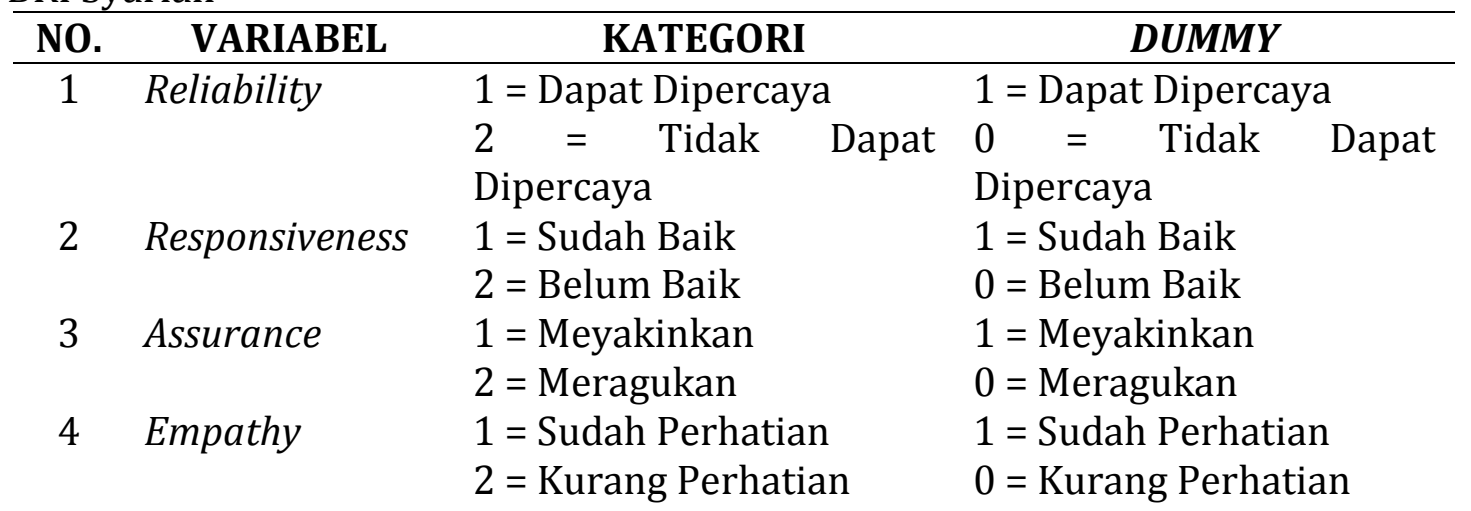


Sumber: Kuesioner, data diolah

Dalam penelitian ini terdapat 2 variabel yang digunakan, yaitu variabel independen dan variabel dependen. Variabel independen dalam penelitian ini dibagi menjadi 4 variabel, di antaranya adalah:

\section{Reliability}

Reliability adalah kemampuan untuk memberikan pelayanan yang sesuai dengan janji yang ditawarkan (Santi, 2004 ). Kategori pada variabel ini terbagi menjadi dua, yaitu:

$1=$ Dapat Dipercaya

$2=$ Tidak Dapat Dipercaya

$2 . \quad$ Responsiveness

Responsiveness adalah respon atau kesigapan karyawan dalam membantu konsumen dan memberikan pelayanan yang cepat dan tanggap ( Santi, 2004 ). Kategori pada variabel ini terbagi menjadi dua, yaitu:

$1=$ Sudah Baik

$2=$ Belum Baik

\section{Assurance}

Assurance meliputi kemampuan karyawan atas pengetahuan terhadap produk secara tepat, kualitas keramah-tamahan, perhatian dan kesopanan dalam memberikan pelayanan, keterampilan dalam memberikan informasi, kemampuan dalam memberikan keamanan didalam memanfaatkan jasa yang ditawarkan dan kemampuan dalam menanamkan kepercayaan konsumen terhadap perusahaan ( Santi, 2004 ). Kategori pada variabel ini terbagi menjadi dua, yaitu:

$1=$ Meyakinkan

$2=$ Meragukan

4. Empathy

Empathy adalah perhatian secara individual yang diberikan
$1=$ Puas

$0=$ Biasa Saja

perusahaan kepada konsumen (Santi, 2004 ). Kategori pada variabel ini terbagi menjadi dua, yaitu:

$1=$ Sudah Perhatian

$2=$ Kurang Perhatian

Sementara itu variabel dependen dalam penelitian ini merupakan kepuasan nasabah BRI Syariah, dimana kategori pada variabel ini terbagi menjadi dua, yaitu:

1 = Puas

2 = Biasa Saja

\section{HASIL DAN PEMBAHASAN}

Akun twitter BRI Syariah telah dibuat sejak tanggal 31 Agustus 2010 dengan nama akun @BRISyariah. Akun tersebut telah menjaring sekitar 68.208 followers dan memiliki jumlah tweet terbanyak di antara akun bank syariah lainnya sebanyak 32.538 tweets. Adanya akun tersebut diharapkan dapat memudahkan interaksi para nasabahnya yang aktif dalam media sosial twitter dengan pihak BRI Syariah, yang diharapkan juga dapat meningkatkan kepuasan mereka. Adapun aktivitas akun twitter @BRISyariah sendiri dibagi menjadi beberapa bagian dalam tweet-nya, di antaranya adalah:

1. Tweet berupa quotes merupakan tweet yang di-share akun @BRISyariah, yang berisikan tentang kata-kata semangat dan lainnya yang ditujukan kepada para followers-nya.

2. Tweet berupa kuis merupakan tweet yang dibuat akun @BRISyariah yang dibagi kedalam beberapa bagian, dimana di setiap bagian tersebut berisi tentang tata cara dan syarat untuk mengikuti kuis tersebut.

3. Tweet berupa pemberian informasi merupakan tweet yang diberikan akun @BRISyariah terhadap followers-nya terkait dengan layanan BRI Syariah. Ada 
bermacam-macam tweet berupa informasi yang diberikan oleh akun @BRISyariah terkait dengan pelayanannya yang diberikan. Biasanya tweet tersebut berupa tweet yang dishare langsung kepada semua followersnya pada waktu tertentu. Terkadang juga tweet yang diberikan oleh akun @BRISyariah ini di-reply oleh followersnya yang ingin menanyakan informasi lebih dalam lagi, karena mungkin tweet berupa informasi yang diberikan akun @BRISyariah ini kurang lengkap. Bisa juga suatu informasi muncul dari pertanyaan salah satu followers-nya, lalu tweet berupa pertanyaan dari nasabahnya ini di-reply oleh akun @BRISyariah.

4. Tweet mengenai promo produk merupakan sebuah tweet yang dibuat oleh akun@BRISyariah guna mempromosikan produk-produk dari BRI Syariah, yang di-share kepada semua followers-nya pada suatu waktu tertentu.

5. Tweet yang disertai foto merupakan sebuah tweet yang dibuat oleh akun @BRISyariah yang disertai dengan sebuah foto, yang di-share kepada seluruh followers-nya pada suatu waktu tertentu.

6. Tweet untuk membina hubungan yang baik dengan nasabah merupakan aktivitas yang dilakukan akun @BRISyariah dalam rangka menjaga hubungan yang baik dengan nasabahnya, dimana hal tersebut bisa dilakukan lewat retweet atau reply terhadap nasabahnya.

Responden yang dijadikan sampel adalah nasabah BRI Syariah yang menjadi followers akun twitter @BRISyariah dan ditentukan berdasarkan teknik accidental sampling, dimana teknik ini merupakan teknik penentuan sampel berdasarkan kebetulan, yaitu siapa yang kebetulan peneliti lihat dan jika dipandang cocok maka dapat dijadikan sampel. Berikut merupakan beberapa karakteristik responden berdasarkan hasil dari penyebaran kuesioner online yang telah dilakukan peneliti.

1. Jenis Kelamin Responden

Tabel 2. Jenis Kelamin Responden

$\begin{array}{cccc}\text { NO. } & \text { JENIS KELAMIN } & \text { JUMLAH RESPONDEN } & \text { PERSENTASE } \\ 1 & \text { Laki-Laki } & 14 & 46,66 \% \\ 2 & \text { Perempuan } & 16 & 53,33 \% \\ & \text { Jumlah } & 30 & 100 \%\end{array}$

Sumber : Kuesioner, data diolah

Dari tabel di atas dapat diketahui jenis kelamin dari 30 nasabah BRI Syariah yang aktif di media sosial twitter, dimana yang berjenis kelamin laki-laki terdapat sebanyak 14 orang $(46,66 \%)$ dan yang berjenis kelamin perempuan sebanyak 16 orang (53,33\%). Dari hasil tersebut perbedaan antara jumlah perempuan dan laki-laki dalam penelitian ini hanya berbeda sedikit saja, walaupun demikian jumlah perempuan mendominasi dalam penelitian ini. Oleh karena itu dari hasil tersebut penulis dapat memberikan gambaran mengenai karakteristik nasabah BRI Syariah yang menjadi followers akun @BRISyariah berdasarkan jenis kelaminnya, dimana jenis kelamin perempuan mendominasi dengan 
persentase $53,33 \%$, lalu diikuti oleh laki-

laki dengan persentase 46,66\%.

2. Pendidikan Responden

Tabel 3 Pendidikan Responden

\begin{tabular}{cccc}
\hline NO. & PENDIDIKAN & JUMLAH RESPONDEN & PERSENTASE \\
\hline 1 & SMA & 14 & $46,66 \%$ \\
2 & D3 & 3 & $10 \%$ \\
3 & S1 & 12 & $40 \%$ \\
4 & S2 & 0 & 0 \\
5 & S3 & 0 & 0 \\
6 & Lainnya & 1 & $3,33 \%$ \\
& Jumlah & $\mathbf{3 0}$ & $\mathbf{1 0 0 \%}$ \\
\hline
\end{tabular}

Sumber: Kuesioner, data diolah

Pada tabel di atas dapat diketahui pendidikan dari 30 nasabah BRI Syariah yang aktif di media sosial twitter, dimana pada penelitian ini nasabah dari SMA terdapat 14 orang (46,66\%), D3 terdapat 3 orang (10\%), S1 terdapat 12 orang (40\%), S2 dan S3 tidak ada sama sekali dan lainnya terdapat 1 orang $(3,33 \%)$. Sehingga dari hasil tersebut penulis dapat memberikan gambaran mengenai karakteristik nasabah BRI Syariah berdasarkan pendidikannya, dimana dalam penelitian ini yang paling dominan adalah dari SMA dengan persentase $46,66 \%$, sedangkan yang tidak ada sama sekali adalah dari pendidikan S2 dan S3. Pada penelitian ini untuk mereka yang pendidikan terakhir SMA rata-rata masih muda dan untuk demografi pengguna twitter di Indonesia sendiri didominasi oleh mereka yang masih muda ( Rahadian, 2013 ). Sehingga hal tersebut juga mungkin berpengaruh terhadap karakteristik pendidikan responden pada penelitian ini, dimana pada penelitian ini untuk karakteristik pendidikan responden di dominasi oleh mereka dengan pendidikan terakhir SMA. Mereka juga aktif di media sosial twitter dan menjadi followers akun @BRISyariah, karena merupakan bagian dari nasabah BRI Syariah.

3. Usia Responden

Tabel 4 Usia Responden

\begin{tabular}{cccc}
\hline NO. & USIA & JUMLAH RESPONDEN & PERSENTASE \\
\hline 1 & $17-22$ Tahun & 17 & $56,66 \%$ \\
2 & $23-28$ Tahun & 11 & $36,66 \%$ \\
3 & $\geq 29$ Tahun & 2 & $6,66 \%$ \\
& Jumlah & $\mathbf{3 0}$ & $\mathbf{1 0 0 \%}$ \\
\hline
\end{tabular}

Sumber: Kuesioner, data diolah 
Dari tabel di atas dapat diketahui usia dari 30 nasabah BRI Syariah yang aktif di media sosial twitter, dimana untuk usia dari 17 sampai 22 tahun terdapat sebanyak 17 orang $(56,66 \%)$, usia dari 23 sampai 28 tahun terdapat sebanyak 11 orang $(36,66 \%)$ dan usia lebih dari sama dengan 29 tahun hanya terdapat 2 orang $(6,66 \%)$. Sehingga dari hasil tersebut penulis dapat memberikan gambaran mengenai karakteristik nasabah BRI Syariah berdasarkan usianya, dimana dalam penelitian ini yang paling dominan adalah usia dari 17 sampai 22 tahun dengan jumlah setengahnya lebih bila dibandingkan dengan rentang usia yang lainnya, dengan persentase sebesar $56,66 \%$, sedangkan yang paling sedikit adalah dari usia lebih dari sama dengan 29 tahun dengan persentase hanya sebesar 6,66\%. Sehingga berdasarkan sampel yang didapatkan dalam penelitian ini, yang lebih banyak aktif dalam media sosial twitter ini adalah mereka yang masih berusia muda. Sementara itu seperti dapat kita ketahui bahwa Indonesia adalah negara dengan bentuk demografi piramida, dimana penduduk usia muda ada di bagian bawah piramida atau yang paling banyak dan menopang penduduk usia tua. Lalu ditambah lagi bahwa dari sisi demografi pengguna twitter di Indonesia secara umum ratarata didominasi oleh mereka yang masih berusia muda ( Rahadian, 2013 ). Sehingga ini merupakan kesempatan bagi perbankan syariah, khususnya BRI Syariah untuk meningkatkan pangsa pasarnya terhadap generasi muda yang aktif di jejaring sosial twitter.

4. Jenis Pekerjaan Responden

Tabel 5 Jenis Pekerjaan Responden

\begin{tabular}{cccc}
\hline NO. & JENIS PEKERJAAN & JUMLAH RESPONDEN & PERSENTASE \\
\hline 1 & Karyawan Swasta & 6 & $20 \%$ \\
2 & PNS & 0 & 0 \\
3 & BUMN & 1 & $3,33 \%$ \\
4 & Profesional (Pengacara, & 3 & $10 \%$ \\
5 & Notaris, Dokter) & 4 & $13,33 \%$ \\
6 & Wiraswasta & 15 & $50 \%$ \\
7 & Pelajar/Mahasiswa & 1 & $3,33 \%$ \\
& Lainnya & 30 & $100 \%$
\end{tabular}

Sumber: Kuesioner, data diolah

Pada tabel di atas dapat diketahui jenis pekerjaan dari 30 nasabah BRI Syariah yang aktif di media sosial twitter, dimana pada penelitian ini untuk karyawan swasta terdapat sebanyak 6 orang (20\%), PNS tidak ada sama sekali, BUMN sebanyak 1 orang $(3,33 \%)$, profesional (pengacara, notaris, dokter) sebanyak 3 orang (10\%), wiraswasta sebanyak 4 orang $(13,33 \%)$, pelajar/mahasiswa sebanyak 15 orang
(50\%) dan lainnya sebanyak 1 orang (3,33\%). Bisa dilihat untuk pelajar/mahasiswa sangat mendominasi dengan jumlah setengahnya dibandingkan dengan jenis pekerjaan lainnya dengan persentase sebesar 50\%. Hal tersebut mungkin disebabkan karena pelajar/mahasiswa memiliki lebih banyak waktu luang dibandingkan dengan jenis pekerjaan lainnya, disamping mereka juga 
mungkin mengenal media sosial seperti twitter ini bisa dari teman-temannya. Sehingga dengan begitu di waktu luangnya itu mereka manfaatkan untuk bermain di media sosial twitter ini dan menjadi followers akun @BRISyariah, karena mereka merupakan nasabah BRI Syariah.

5. Pendapatan Responden

Tabel 6 Pendapatan Responden

\begin{tabular}{cccc}
\hline NO. & PENDAPATAN & JUMLAH RESPONDEN & PERSENTASE \\
\hline 1 & $\leq \mathrm{Rp} \mathrm{2.500.000}$ & 24 & $80 \%$ \\
2 & $\mathrm{Rp} \mathrm{2.500.001-Rp} \mathrm{5.000.000}$ & 5 & $16,66 \%$ \\
3 & $\mathrm{Rp} \mathrm{5.000.001-Rp} \mathrm{7.500.000}$ & 1 & $3,33 \%$ \\
4 & $\mathrm{Rp} \mathrm{7.500.001-Rp}$ & 0 & 0 \\
5 & 10.000 .000 & 0 & 0 \\
& $\geq$ Rp 10.000.001 & $\mathbf{3 0}$ & $\mathbf{1 0 0 \%}$
\end{tabular}

Sumber: Kuesioner, data diolah

Pada tabel di atas dapat

oleh nasabah dengan pendapatan kurang dari sama dengan Rp 2.500.000,- dengan perolehan persentase sebesar $80 \%$.

diketahui pendapatan dari 30 nasabah BRI Syariah yang aktif di media sosial twitter, dimana untuk pendapatan kurang dari sama dengan $\mathrm{Rp} 2.500 .000$,- terdapat sebanyak 24 orang (80\%), pendapatan antara $\mathrm{Rp} 2.500 .001$ sampai dengan $\mathrm{Rp}$ 5.000 .000 ,- sebanyak 5 orang $(16,66 \%)$, pendapatan antara Rp 5.000.001,-- sampai dengan Rp 7.500.000,-- sebanyak 1 orang (3,33\%). Sementara itu untuk pendapatan antara Rp 7.500.001,-- sampai dengan Rp 10.000 .000 ,- dan di atas dari sama dengan Rp 10.000.001 tidak ada sama sekali. Sehingga berdasarkan sampel yang didapatkan, nasabah BRI Syariah yang Pada penelitian ini uji reliabilitas dilakukan dengan melihat koefisien Cronbach Alpha yang dapat diartikan sebagai hubungan positif antara pertanyaan satu dengan yang lainnya. Suatu instrumen penelitian dinyatakan reliabel jika memiliki nilai Alpha berkisar antara 0,60 - 0,70. Dasar pengambilan keputusan adalah:

Jika Cronbach Alpha > 0,60 construct reliable Jika Cronbach Alpha $<0,60$ construct not reliable (Yvonne dan Robert, menjadi followers akun @BRISyariah 2013) dalam penelitian ini sangat didominasi

Berikut merupakan hasil uji reliabilitas dengan menggunakan SPSS versi 20:

Tabel 7 Nilai Statistik Reliabilitas

\begin{tabular}{rr}
\hline \multicolumn{2}{c}{ Reliability Statistics } \\
$\begin{array}{c}\text { Cronbach's } \\
\text { Alpha }\end{array}$ & $\begin{array}{c}\text { N of } \\
\text { Items }\end{array}$ \\
\hline .916 & 16 \\
\hline
\end{tabular}

Sumber: Kuesioner, data diolah

Pada tabel di atas, kolom Cronbach Alpha menunjukkan nilai statistik sebesar 0,916. Sehingga ini menggambarkan bahwa untuk 16 pertanyaan yang diajukan kepada responden adalah reliabel, karena 
sesuai dengan dasar pengambilan keputusan bahwa 0,916 $>0,60$.

Untuk uji validitas sendiri ditentukan berdasarkan koefisien korelasi $(r)$, dimana jika $r$ hitung $\geq r$ tabel, maka instrumen tes yang diujicobakan tersebut dapat dinyatakan valid (Burhan, Gunawan dan Marzuki, 2012). Tingkat validitas pada penelitian ini dapat dilihat pada Corrected Item-Total Correlation yang merupakan korelasi antara skor item dengan skor total item (nilai $r$ hitung) dibandingkan dengan nilai $r$ tabel. Dengan menggunakan distribusi (Tabel r) untuk $\alpha=0,05$ dengan derajat kebebasan $(\mathrm{dk}=\mathrm{n}-1=30-1$ =29) sehingga didapat $r$ tabel $=0,367$ (Riduan, Adun dan Enas, 2013). Berikut merupakan hasil uji validitas dengan menggunakan SPSS versi 20

Tabel 8 Hasil Uji Validitas

\begin{tabular}{lrrrr}
\hline & \multicolumn{3}{c}{ Item-Total Statistics } \\
& $\begin{array}{l}\text { Scale Mean if } \\
\text { Item Deleted }\end{array}$ & $\begin{array}{c}\text { Scale } \\
\text { Variance if } \\
\text { Item Deleted }\end{array}$ & $\begin{array}{c}\text { Corrected } \\
\text { Item-Total } \\
\text { Correlation }\end{array}$ & $\begin{array}{c}\text { Cronbach's } \\
\text { Alpha if Item } \\
\text { Deleted }\end{array}$ \\
\hline p1 & 46.3667 & 35.344 & .429 & .915 \\
p2 & 46.2000 & 34.993 & .398 & .916 \\
p3 & 46.1000 & 34.300 & .469 & .914 \\
p4 & 46.4000 & 30.800 & .821 & .903 \\
p5 & 46.5333 & 31.913 & .610 & .911 \\
p6 & 46.6000 & 30.593 & .701 & .908 \\
p7 & 46.1000 & 33.197 & .583 & .911 \\
p8 & 46.0667 & 32.133 & .749 & .906 \\
p9 & 46.3000 & 33.114 & .674 & .909 \\
p10 & 46.4333 & 31.564 & .743 & .906 \\
p11 & 45.8333 & 32.282 & .692 & .908 \\
p12 & 46.1333 & 32.257 & .676 & .908 \\
p13 & 45.9667 & 33.895 & .499 & .913 \\
p14 & 46.5000 & 32.259 & .583 & .912 \\
p15 & 46.5000 & 32.052 & .612 & .910 \\
p16 & 46.9667 & 33.620 & .475 & .914 \\
& & & Valid All Variable \\
\hline
\end{tabular}

Sumber: Kuesioner, data diolah

Pada tabel di atas terdapat kolom Corrected Item-Total Correlation yang menunjukkan nilai validitas dari pertanyaan atau pernyataan nomor 1 (p1) sampai dengan pernyataan nomor 16 (p16). Di kolom tersebut nilai statistik yang dihasilkan dari mulai p1 sampai dengan p16 lebih besar dari 0,367. Sehingga semua pernyataan yang dipakai untuk mengetahui pengaruh aktivitas media twitter BRI Syariah terhadap kepuasan nasabah BRI Syariah adalah valid.

Selanjutnya adalah analisis regresi logistik, dimana pada bagian ini akan dilihat pengaruh dari setiap variabel aktivitas media twitter BRI Syariah terhadap kepuasan nasabah BRI Syariah, dimana pengolahan data dilakukan dengan menggunakan SPSS versi 20. Pengambilan keputusannya sendiri dilihat dari probabilitas Chi Squares, dimana jika probabilitas Chi Squares lebih kecil dari tingkat signifikansi $(\alpha=5 \%)$, maka signifikan 
dan sebaliknya jika Chi Squares lebih besar dari tingkat signifikansi $(\alpha=$ $5 \%$ ), maka tidak signifikan (Agus, 2010). Untuk interpretasinya dilakukan lewat angka Odds ratio, dimana dalam SPSS versi 20 terdapat pada kolom $\operatorname{Exp(B)~(Agus,~2010).~}$

1. Pengaruh Variabel Reliability terhadap Kepuasan Nasabah BRI Syariah

Warnings
Estimation cannot be performed because no
variables remain.

Gambar 3. Hasi Uji Regresi Logistik Variabel Reliability

Sumber: Kuesioner, data diolah

Pada gambar diatas analisis regresi logistik tidak dapat diterapkan untuk variabel reliability, penyebabnya karena analisis ini sendiri harus mensyaratkan 2 kondisi, yaitu harus ada jawaban nasabah yang masuk ke kategori 1 dan juga harus ada jawaban nasabah yang masuk ke kategori 2. Pada penelitian ini kategori pertama dari

variabel reliability ini adalah "tidak dapat dipercaya" dan kategori keduanya adalah "dapat dipercaya". Sedangkan dalam penelitian ini dari semua responden yang mengisi kuesioner tentang reliability, semuanya masuk ke kategori 2, yaitu kategori "dapat dipercaya" sehingga tidak dapat dilakukan analisis regresi logistik.

2. Pengaruh Variabel Responsiveness terhadap Kepuasan Nasabah BRI Syariah Tabel 9 Hasil Uji Regresi Logistik Variabel Responsiveness

\begin{tabular}{llccccccr}
\hline \multicolumn{9}{c}{ Variables in the Equation } \\
& \multicolumn{9}{c}{ B } & S.E. & Wald & df & Sig. & Exp(B) \\
\hline Step 1a & $\begin{array}{l}\text { Responsiveness } \\
\text { (1) }\end{array}$ & .944 & .445 & 4.496 & 1 & .034 & 2.571 \\
\hline
\end{tabular}

Sumber: Kuesioner, data diolah

a. Variable(s) entered on step 1: responsiveness.

Pada tabel di atas merupakan

hasil dari uji regresi logistik, dimana variabel responsiveness memiliki nilai sig. $0,034<0,05$. Nilai tersebut menunjukkan bahwa variabel responsiveness berpengaruh secara signifikan terhadap kepuasan nasabah BRI Syariah. Berarti bila setiap kali akun @BRISyariah mereply tweet nasabahnya, maka hal tersebut dapat menghilangkan peluang anggapan dari para nasabahnya kepada akun @BRISyariah bahwa reply yang diberikan belum baik dan memberikan peluang kepuasannya sebanyak 2,571 kali daripada peluang menghilangkan anggapan sudah baik.
Responsiveness sendiri merupakan respon atau kesigapan karyawan dalam membantu konsumen dan memberikan pelayanan yang cepat dan tanggap, yang meliputi; kesigapan karyawan dalam melayani konsumen, kecepatan karyawan dalam menangani transaksi dan cara penanganannya ( Santi, 2004 ). Bila dihubungkan dengan aktivitas akun twitter @BRISyariah, berarti respon atau kesigapan akun @BRISyariah dalam membantu nasabahnya yang merupakan followers dari akun tersebut. Responnya sendiri ditunjukan lewat reply yang diberikannya kepada setiap nasabahnya. Sehingga reply 
yang diberikan akun @BRISyariah ini berkontribusi dalam meningkatkan kepuasan nasabah BRI Syariah yang menjadi followers akun tersebut. Adapun hal-hal yang membuat a. Respon atau kesigapan akun @BRISyariah dalam me-reply tweet para nasabahnya tidak mengecewakan, artinya setiap nasabah BRI Syariah yang membutuhkan informasi dan menanyakannya langsung kepada akun@BRISyariah, maka berdasarkan penelitian ini reply dari akun @BRISyariah ini tidak mengecewakan.

b. Akun@BRISyariah dapat dengan cepat menangani setiap variabel responsiveness ini mempunyai pengaruh terhadap kepuasan nasabah BRI Syariah di antaranya:

$$
\begin{aligned}
& \text { pertanyaan dan keluhan } \\
& \text { nasabahnya. }
\end{aligned}
$$

c. Admin @BRISyariah memiliki kemampuan dalam menangani beragam keluhan nasabahnya.

Nilai koefisien regresinya adalah 0,944. Maka model yang dapat dibentuk adalah:

$Y_{i}=0,944$ responsiveness

3. Pengaruh Variabel Assurance terhadap Kepuasan Nasabah BRI Syariah Tabel 10. Hasil Uji Regresi Logistik Variabel Assurance

\begin{tabular}{llccccccr}
\hline \multicolumn{8}{c}{ Variables in the Equation } \\
& B & S.E. & Wald & df & Sig. & Exp(B) \\
\hline Step 1 $1^{\text {a }} \begin{array}{l}\text { assurance(1 } \\
\text { ) }\end{array}$ & .965 & .415 & 5.396 & & 1 & .020 & 2.625 \\
\hline
\end{tabular}

a. Variable(s) entered on step 1: assurance.

Sumber: Kuesioner, data diolah

Pada tabel di atas merupakan hasil uji regresi logistik, dimana variabel assurance berpengaruh secara signifikan terhadap kepuasan nasabah BRI Syariah, karena memiliki nilai sig. 0,020<0,05. Hal ini berarti bila setiap kali akun @BRISyariah memberikan tweet yang berhubungan dengan dimensi kualitas pelayanan assurance, maka hal tersebut dapat menghilangkan peluang anggapan dari para nasabahnya bahwa setiap tweet yang diberikan akun @BRISyariah itu meragukan kebenarannya, sehingga memberikan peluang kepuasannya sebanyak 2,625 kali dari pada peluang menghilangkan anggapan bahwa akun @BRISyariah meyakinkan.

Assurance sendiri meliputi kemampuan karyawan atas pengetahuan terhadap produk secara tepat, kualitas keramah-tamahan, perhatian dan kesopanan dalam memberikan pelayanan, keterampilan dalam memberikan informasi, kemampuan dalam memberikan keamanan didalam memanfaatkan jasa yang ditawarkan dan kemampuan dalam menanamkan kepercayaan konsumen terhadap perusahaan (Ibid). Bila dihubungkan dengan aktivitas akun twitter @BRISyariah, berarti kemampuan yang dimiliki admin @BRISyariah atas pengetahuan terhadap produk BRI Syariah secara tepat, perhatian yang diberikan, keterampilan dalam memberikan informasi, kemampuan dalam memberikan keamanan serta kemampuan dalam menanamkan kepercayaan nasabah terhadap BRI Syariah. Sehingga setiap tweet yang berkaitan dengan dimensi kualitas 
pelayanan assurance ini berkontribusi dalam meningkatkan kepuasan nasabah yang menjadi followers akun tersebut. Adapun hal-hal yang membuat variabel assurance ini mempunyai pengaruh terhadap kepuasan nasabah BRI Syariah di antaranya:

a. Admin @BRISyariah menguasai betul tentang produk-produk BRI Syariah yang ada, sehingga dengan begitu keberadaan akun @BRISyariah tidak diragukan oleh para nasabahnya.

b. Setiap tweet yang diberikan akun@BRISyariah tidak diragukan lagi oleh para nasabahnya. Sehingga para nasabah yang menjadi followers akun@BRISyariah tidak mengkhawatirkan lagi tweet akun@BRISyariah ini asli atau tidak. c. Akun@BRISyariah selalu membina hubungan yang baik dengan para nasabahnya. Contohnya seperti retweet yang dilakukan akun @BRISyariah terhadap sebuah pendapat nasabahnya.

d. Akun @BRISyariah senantiasa memberikan pelayanan yang maksimal terhadap nasabahnya.

e. Adanya kuis BRI Syariah yang membuat akun @BRISyariah menjadi lebih menarik.

f. Di bidang kategori sosial media, akun @BRISyariah merupakan akun yang terbaik menurut para nasabahnya.

Nilai koefisien regresinya adalah 0,965 . Maka model yang dapat dibentuk adalah:

$$
Y_{i}=0,965 \text { assurance }
$$

4. Pengaruh Variabel Empathy terhadap Kepuasan Nasabah BRI Syariah

Tabel 11. Hasil Uji Regresi Logistik Variabel Empathy

\begin{tabular}{|c|c|c|c|c|c|c|}
\hline \multicolumn{7}{|c|}{ Variables in the Equation } \\
\hline & $\mathrm{B}$ & S.E. & Wald & Df & Sig. & $\operatorname{Exp}(B)$ \\
\hline $\begin{array}{l}\text { Step } 1^{\text {a }} \text { empathy } \\
\text { 1) } \\
\text { a. Variable(s) enter }\end{array}$ & $\begin{array}{l}.981 \\
\text { step }\end{array}$ & $\begin{array}{r}.479 \\
\text { mpath }\end{array}$ & 4.198 & & .040 & 2.667 \\
\hline
\end{tabular}

Sumber: Kuesioner, data diolah

Tabel di atas menunjukkan hasil regresi logistik, dimana variabel empathy memiliki nilai sig. 0,040 < 0,05 . Hal tersebut menunjukkan bahwa variabel empathy berpengaruh secara signifikan terhadap kepuasan nasabah BRI Syariah. Sehingga bila

memberikan peluang kepuasannya sebanyak 2,667 kali dibandingkan dengan peluang menghilangkan anggapan bahwa akun @BRISyariah sudah perhatian.

Empathy sendiri merupakan perhatian secara individual yang setiap kali akun @BRISyariah memberikan tweet yang berhubungan dengan dimensi kualitas pelayanan empathy kepada nasabahnya, maka dapat menghilangkan peluang anggapan dari para nasabahnya bahwa akun @BRISyariah kurang perhatian terhadap mereka

diberikan perusahaan kepada konsumennya, seperti kemudahan untuk menghubungi perusahaan, kemampuan karyawan untuk berkomunikasi dengan konsumen 
dan usaha perusahaan untuk memahami keinginan dan kebutuhan konsumennya ( Santi:2004 ). Bila dihubungkan dengan aktivitas twitter @BRISyariah, berarti perhatian secara individual yang diberikan oleh akun twitter @BRISyariah terhadap nasabahnya. Sehingga setiap perhatian yang diberikan akun @BRISyariah lewat tweet kepada nasabahnya ini memiliki kontribusi dalam meningkatkan kepuasan nasabah BRI Syariah. Adapun hal-hal yang membuat variabel empathy ini mempunyai pengaruh terhadap kepuasan nasabah BRI Syariah di antaranya:

\section{KESIMPULAN DAN IMPLIKASI}

Berdasarkan penelitian yang telah dilakukan terhadap nasabah BRI Syariah yang menjadi followers akun @BRISyariah, maka kesimpulan yang dapat dihasilkan adalah sebagai berikut:

1. Aktivitas akun @BRISyariah sendiri dalam penelitian ini dibagi ke dalam beberapa bagian berdasarkan jenis tweet-nya, di antaranya yang pertama tweet berupa quotes, dimana akun @BRISyariah memberikan tweet yang berisi tentang kata-kata semangat dan lain sebagainya. Tweet yang kedua merupakan tweet berupa kuis yang dilakukan terhadap para nasabah BRI Syariah yang menjadi followers akun @BRISyariah. Tweet yang ketiga merupakan tweet berupa informasi terkait dengan pelayanannya yang diberikan. Lalu tweet yang keempat merupakan tweet mengenai produk, dimana akun @BRISyariah mempromosikan tentang segala produk BRI Syariah. Tweet yang kelima merupakan tweet yang disertai foto yang di-share kepada para followers-nya, contohnya seperti foto tentang penghargaan dan foto-foto event. Tweet yang keenam a. Akun @BRISyariah memberikan kemudahan dalam berkomunikasi terhadap nasabahnya.

b. Akun@BRISyariah sering melakukan interaksi terhadap nasabahnya.

c. Kebutuhan nasabah BRI Syariah terhadap informasi sudah dapat terpenuhi dengan adanya akun @BRISyariah.

d. Akun @BRISyariah selalu memberikan quotes (kata-kata bermakna) setiap harinya.

Nilai koefisien regresinya adalah 0,981 . Maka model yang dapat dibentuk adalah: $Y_{i}=0,981$ empathy.

merupakan tweet yang diberikan oleh akun@BRISyariah@kepada nasabahnya, yang bertujuan untuk membina hubungan yang baik dengan mereka.

2. Dari hasil analisis data yang dilakukan dapat diketahui bahwa dari 4 variabel yang diteliti, untuk variabel reliability tidak dapat dilakukan analisis regresi logistik, dikarenakan jawaban responden semuanya masuk ke salah satu kategori saja, yaitu kategori "dapat dipercaya". Variabel responsiveness memiliki nilai sig. $0,034<0,05$ yang berarti variabel responsiveness berpengaruh terhadap kepuasan nasabah BRI Syariah. Variabel assurance memiliki nilai sig. $0,020<0,05$ yang berarti variabel assurance juga berpengaruh terhadap kepuasan nasabah BRI Syariah. Begitu juga variabel empathy berpengaruh terhadap kepuasan nasabah BRI Syariah, karena memiliki nilai sig. $0,040<0,05$. Pada ketiga variabel tersebut, variabel empathy memiliki nilai odds ratio lebih besar dibandingkan dengan variabel lainnya, yaitu sebesar 2,667. Sehingga setiap perhatian yang diberikan akun 
@BRISyariah lewat tweet terhadap nasabahnya, memiliki kontribusi paling besar dalam meningkatkan kepuasan mereka dibandingkan dengan variabel lainnya.

$$
\text { Penulis menyadari masih }
$$

terdapat keterbatasan di dalam penelitian ini. Sehingga penelitian ini diharapkan dapat memberikan informasi dan masukkan bagi penulis ataupun pihak-pihak yang berkepentingan:

1. BRI Syariah perlu menjalin relasi di dunia nyata dengan para followers akun twitternya. Hal tersebut dikarenakan situs jejaring sosial twitter merupakan bagian dari dunia maya. Sehingga relasi yang dilakukan tidak lain untuk merealisasikan jumlah followers-nya di dunia nyata.

2. Perhatian secara individual yang dilakukan oleh akun @BRISyariah terhadap nasabahnya yang aktif di situs jejaring sosial twitter diharapkan dapat lebih ditingkatkan lagi. Hal tersebut dikarenakan dalam penelitian ini variabel empathy memiliki nilai odds ratio lebih besar dibandingkan dengan yang lainnya.

3. BRI Syariah perlu terbuka terhadap para followers-nya tentang kekurangan akun twitternya dan meminta saran kepada mereka, dimana saran tersebut bisa dijadikan

\section{DAFTAR PUSTAKA}

Augustine, Yvonne dan Kristaung, Robert. 2013. Metodologi Penelitian Bisnis dan Akuntansi. Dian Rakyat: Jakarta.

BESRAL. 2010. Pengolahan dan Analisa Data-1 Menggunakan SPSS, (http://www.slideshare.net/in_ndah/ modul-belajarspss1) diakses pada tanggal 05 Maret 2014.

DGtraffic. 2013. Research of Internet Users for 2013, (http://www.dgtraffic.com/articles/detail /30/11/-0001/160/research-of-internet- masukan untuk BRI Syariah dan menjadikan akun twitternya lebih baik lagi dari sebelumnya.

4. BRI Syariah perlu menunjuk secara jelas pihak yang dapat menyelesaikan permasalahan khusus di media sosial twitter. Contohnya seperti tweet nasabah BRI Syariah yang tidak sempat di reply oleh akun twitter @BRISyariah.

5. Pada penelitian ini nasabah BRI Syariah yang menjadi followers akun @BRISyariah tidak dapat diketahui secara jelas. Sehingga untuk penelitian yang sama di masa yang akan datang, diharapkan terdapat sebuah metode untuk mengetahui seluruh nasabah BRI Syariah yang menjadi followers akun @BRISyariah. Sehingga dengan begitu metode pengambilan sampelnya pun dapat berbeda dengan metode yang digunakan di dalam penelitian ini dan hasilnya pun dapat dijadikan sebagai pembanding, yang mungkin dapat dijadikan bahan rujukan untuk penelitian selanjutnya.

6. Pada penelitian selanjutnya mungkin dapat digunakan variabel-variabel yang berbeda yang tidak tercantumkan dalam penelitian ini, untuk mengetahui seberapa besar variabel tersebut mempengaruhi kepuasan nasabah BRI Syariah.

users-for-2013) diakses pada tanggal 03 Oktober 2013.

Gujarati, Damodar. 1997. Ekonomimetrika Dasar. Erlangga: Jakarta.

Lestariningsih. 2011. Uji Validitas dan Uji Reliabilitas,

(http://p4mristkippgrisda.wordpress .com/2011/05/10/uji-validitas-danreliabilitas/) diakses pada tanggal 20 Januari 2014.

Nurgiyantoro, Burhan., Gunawan., Marzuki. 2012. Statistik Terapan untuk 
Penelitian Ilmu-Ilmu Sosial. GADJAH MADA UNIVERSITY PRESS: Yogyakarta.

P. Paramita, Rahadian. 2013. Statistik Pengguna Twitter Indonesia Oktober 2013, (http://beritagar.com/p/statistikpengguna-twitter-indonesia-oktober2013-10207) diakses pada tanggal 20 Maret 2014

Parmanti Widjaja, Santi. 2004. Analisis Tingkat Kepuasan Konsumen: Studi Kasus di Restoran Rico, (http://thesis.binus.ac.id/doc/a/LHM200 4-0028.pdf) diunggah pada tanggal 12 Januari 2014.

Riduwan., Rusyana, Adun., Enas. 2013. Cara Mudah Belajar SPSS Versi 17.0 dan
Aplikasi Statistik Penelitian. Alfabeta: Bandung.

Siregar, Syofian. 2013. Statistik Parametrik untuk Penelitian Kuantitatif. PT Bumi Aksara: Jakarta.

Widarjono, Agus. 2010. Analisis Statistika Multivariat Terapan. UNIT PENERBIT DAN PERCETAKAN: Yogyakarta.

Wikipedia. 2013.2 Twitter, (http://id.wikipedia.org/wiki/Twitter) diakses pada tanggal 03 Oktober 2013.

Younie. 2011. Chapter 4: Metode Penelitian, (http://virtualyuni.wordpress.com/2011/ 03/08/chapter-4-metodepenelitian/) diakses pada tanggal 16 Januari 2014. 
